\title{
The Linkage between Trade Openness, Energy Consumption, GDP, Urban Population and Carbon Dioxide Emission: Evidence from BRI countries
}

\author{
Nadeem Jan* \\ School of Economics, Zhongnan University of Economics and Law (ZUEL), Wuhan China
}

DOI: $10.36348 /$ sjef.2020.v04i04.003

| Received: 11.04.2020 | Accepted: 23.04.2020 | Published: 27.04.2020

*Corresponding author: Nadeem Jan

\section{Abstract}

This study analyzes the impact of trade openness, economic growth, energy consumption and urban population on carbon dioxide emission by using annual data of 50 Belt and Road countries for the period 1992 to 2014. Further the study also analyzes three regions groups of the Belt and Road. The study applied Pooled OLS, Fixed effect, Random effect and GLS models to the realization of this investigation. The fixed-effect model elicited that trade openness mitigated carbon dioxide emission While economic growth, energy consumption, and urban population has proved to be harmful for the environment in overall sample, GLS also supported the same finding. The empirical results suggest that policymakers should consider to ensure and facilitate more trade openness, reduce the usage of carbon fossil fuel, regulate environmental policy, e.g., Carbon tax or pollution permits on pollution-intensive goods to reduce emission and increase dependency on renewable energy. Moreover, encourage economy liberalization with the intention to bring more investments in energy efficiency technologies and access to products with high energy efficiency as well as create the general public awareness of eco-friendly investments and green energy in BRI economies that reduces carbon dioxide emissions.

Keywords: Trade openness, carbon dioxide emission, economic growth, Belt and Road, fixed effect and FGLS

Copyright @ 2020: This is an open-access article distributed under the terms of the Creative Commons Attribution license which permits unrestricted use, distribution, and reproduction in any medium for non-commercial use (NonCommercial, or CC-BY-NC) provided the original author and source are credited.

\section{INTRODUCTION}

More than 2000 years ago, China imperial Zhang Qian established Silk Road to link China with Asia and the Arab world and to export Silk, that's why called Silk Road. China, the ancient silk route before $5^{\text {th }}$ century BC, for trading and culture exchange to Europe, Middle East, its length more than $1000 \mathrm{~km}$ from China to Rome hence with passage of time it extended to African countries. The first Chinese scholar Professor Wang Jisi speak about the need for China to rejuvenate three silk roads to south Asia, South East Asia, and Central Asia later on when $\mathrm{Xi}$ Jinping came in power in China and during his visit to Kazakhstan and Indonesia where Officially announced for Revitalizing One Belt and One Road initiative in September 2013.

The land-based in termed 'Silk Road Economic Belt (S.R.M) that through it, China connects central Asia, west Asia Middle East, and Europe, and the Sea Route called 'Maritime Silk Route or $21^{\text {st }}$ Century Maritime Silk Route abbreviated by (M.S.R) that links China with East Africa, North Africa, South East Asia, Middle East Oceania The South China Sea, the South Pacific Ocean,, and Indian ocean sea ultimately connects the heart of Mediterranean. Although Belt and Road is the inspiration of Silk Road as a long journey to Belt and Road [1,2]. The aims and development strategy of Belt and Road intuitive that focuses on connectivity's cooperation to encourage a new pattern of trade, stimulate growth, to create the world's largest platform for economic cooperation, financing integration, and people to people exchange across connected countries. The summit 2017 of BRI discussed many aspects for cooperative strategic point of view but emphasis the two key elements the 1 to expand economic growth, investment and trade, and $2^{\text {nd }}$ core policy to encourage infrastructure, institution, Social relation or people to people connectivity among the subjected countries in the BRI Communities. According to Boffa M [3], the vision and objectives of BRI introduced by the Government of China is the winwin goal, which explaining to bring prosperity, development, and peace along with the BRI economies. However, it is a comprehensive package of BRI that has Five main objectives 1st infrastructure connections, 2nd to ensure trade facilitation, 3rd coordination of development strategies a polices $4^{\text {th }}$ financial integration, and $5^{\text {th }}$ people to people exchange. 
As for a geography point of view of BRI, is an open platform for all countries and a new phase of globalization which will connect countries through Roads and maritime. However, there is no official list of BRI countries, However, a different version of the unofficial list exists in the BRI Countries, which is not confirmed by the Government of China (GOC). Nonetheless, the total number of countries are 66 and extendable. These countries encompassed land area $38.5 \%$ out of total global, 30.5 percent GDP out of total global, 62.5 percent population of the world, and the total investment on BRI is considered 4 -8 trillion dollars [3]. World Bank database 2016; Fung Business Intelligence Centre 2016. According to the UN comrade database, the share of 60 Belt and Road economies in world export was $37 \%$ in 2015 out of the world 182 countries. Furthermore, the total export of Europe and Central Asia and East Asia and the Pacific was $80 \%$ from BRI countries additionally Boffa, M [3].

International trade and carbon dioxide emission has noticeable correlation globally, and both are vital for fastest-growing economies and reinforce the development pace as well as it is noted that the total volume of both variables upward trend for the last few decades such as International trade uplift $450 \%$ while $\mathrm{CO}_{2}$ emission increased by $75 \%$ for the period $1980-2012[4,5]$. Further reported that $\mathrm{CO}_{2}$ emission growing ratio and rapid pace are anticipated to be higher at $127 \%$ of developing countries than the developed countries by 2040 [4]. The net effect of trade on environmental is ambiguous and not clear, it may lead to environmental deteriorations or may improve air quality. It is reported that trade openness significantly affected energy consumption by different channels while Carbon dioxide emission just over is driven from energy consumption, thus trade openness is a noteworthy factor of $\mathrm{CO}_{2}$ emission. Nevertheless, trade openness has effected environment by three types, termly scale effect, composition effect and technique effect, Moreover positively impact through scale effect and composition effect on $\mathrm{CO}_{2}$ emission while negatively effected through technique effect on $\mathrm{CO}_{2}$ emission $[6,7]$. Comprehensively by scale effect, trade accelerate the volume of output which consequently deleterious effect on climate change, by composition effect trade may positive or negative impact on $\mathrm{CO}_{2}$ emission, in case of positive impact, a country boast their economic growth and development process by attracting pollution-intensive industries and constructing mega project hence elevate $\mathrm{CO}_{2}$ emission which subsequently contribute to the deterioration of the atmosphere, but when adapted environmental regulation such as carbon tax or emission quota and labor-intensive products as result trade openness mitigate $\mathrm{CO}_{2}$ emission, while technique effect, it improves environmental quality because when trade increase, it standardizes technology and skill which reduce carbon dioxide emission [8].
International trade and carbon dioxide emission has noticeable correlation globally, and both are vital for fastest-growing economies and reinforce the development pace as well as it is noted that the total volume of both variables upward trend for the last few decades such as International trade uplift $450 \%$ while $\mathrm{CO}_{2}$ emission increased by $75 \%$ for the period $1980-2012[4,5]$. Further reported that $\mathrm{CO}_{2}$ emission growing ratio and rapid pace are anticipated to be higher at $127 \%$ of developing countries than the developed countries by 2040 [4]. The net effect of trade on environmental is ambiguous and not clear, it may lead to environmental deteriorations or may improve air quality. It is reported that trade openness significantly affected energy consumption by different channels while Carbon dioxide emission just over is driven from energy consumption, thus trade openness is a noteworthy factor of $\mathrm{CO}_{2}$ emission. Nevertheless, trade openness has effected environment by three types, termly scale effect, composition effect and technique effect, Moreover positively impact through scale effect and composition effect on $\mathrm{CO}_{2}$ emission while negatively effected through technique effect on $\mathrm{CO}_{2}$ emission [6, 7]. Comprehensively by scale effect, trade accelerate the volume of output which consequently deleterious effect on climate change, by composition effect trade may positive or negative impact on $\mathrm{CO}_{2}$ emission, in case of positive impact, a country boast their economic growth and development process by attracting pollution-intensive industries and constructing mega project hence elevate $\mathrm{CO}_{2}$ emission which subsequently contribute to the deterioration of the atmosphere, but when adapted environmental regulation such as carbon tax or emission quota and labor-intensive products as result trade openness mitigate $\mathrm{CO}_{2}$ emission, while technique effect, it improves environmental quality because when trade increase, it standardizes technology and skill which reduce carbon dioxide emission [8].

Furthermore, a large number of studies confirmed that trade openness could also effect environment by two hypotheses, $\mathrm{PHH}$ is labeled as the pollution haven hypothesis which explains that production increase at the cost of environmental pollution in the host entities on the other hand trade openness can reduce environmental pollution by latest term $\mathrm{PHH}$ is known pollution halo hypothesis justified by reason when foreign investors utilize better managerial skills and latest technologies in the host countries and consequently make clean environment and curb environmental degradation, this phenomenon was confirmed by Tang and Tan [9].

The past decades, it was gauged that economic growth depends on labor and capital by the traditional way of production explained by Solow growth model but later on realized that most significant factor for sustainable economic development is energy consumption, A numerous 
literate have been examined that economic growth and energy consumption positively connected each other. Theoretical studies discussed that energy consumption is the vital and complementary factor of capital and another producing process of economic growth, the neoclassical growth theory and endogenous growth theory securitized the essential element of production, e.g., Augmented Solow growth model, 1974. Additionally, investigated that energy consumption is dominated element for the acceleration of comprehensive economic growth and industries; thus, energy consumption has bidirectional relation with economic growth [10]. The impact of energy use examined in Latina America, Western Europe, and Asia and found a direct impact on growth while no causality reported in Middle East [11]. In Asia, the nexus between Growth and energy usage and examined the bidirectional relationship in the long run [12]. The world population is increasing dramatically the demand of different products move with the same direction, to fulfill the required demand of product, need higher energy consumption for running machinery equipment's industrialization and transportation to generate products. BRI is a vast and inclusive platform for global and regional sustainable development; through it, China can help to improve and give new momentum to the global and neighbor countries in the form of mutual benefits, industrialization development, create a new model of global cooperation and trade openness.

The consistently increasing emission level of greenhouse gases (GHG) is significant risk for the environmental quality and living organisms. The greenhouse gas is the combination of different poisonous gases e,g methane, nitrous oxide and carbon dioxide while the ratio of carbon dioxide emission higher than all other emission. However, Greenhouse gas emission is a worldwide problem, whereas the major share $\mathrm{CO}_{2}$ emission at round more than $60 \%$ in GHG. Taking into account, the total economies of BRI are producing approximately $61.4 \%$ emission of the global panel. Even though China is the biggest emitter of $\mathrm{CO}_{2}$ emission globally, the reason behind the second fastest and largest emerging economy of the world and ongoing projects of BRI. The aggregate $\mathrm{CO}_{2}$ emission of BRI is recorded 10049.39 metric tons per capita in 2015 [13, 14]. It documented that international trade and Carbon dioxide has been increased remarkable from the last few decades, whereas aggregate trade volume increased $450 \%$ and $\mathrm{CO}_{2}$ emission 75\% from 1980 to 2014 respectively, and it is also expected that at the current rapid pace of $\mathrm{CO}_{2}$ emission in developing countries will be $127 \%$ higher than advanced countries in 2040 [4, 5].

According to Stern N [15] and WRI [16] predicted that in 21 th century that if no immediate action is taken to control global warming then world temperature will increase at range between $1.1 \mathrm{C}$ to
6.4C and the sea level will be uplift between $15.8 \mathrm{~cm}$ and $16.5 \mathrm{~cm}$ and Carbon dioxide globally will also increase on the same pace such as from 1990 to 2012 $\mathrm{CO}_{2}$ increased from 32414 to $46049 \mathrm{M}_{\mathrm{t}} \mathrm{CO}_{2}$ $\mathrm{e}$ (million metric tons of Carbon dioxide equivalent). Moreover, Global GDP will be adversely affected and will be declined at an estimated rate from $5 \%$ to $20 \%$, as a result, catastrophic consequences will occur in people's lives.

However, as mentioned before that for the last few decades, we are facing climate challenges and getting crucial annually; if we do not act on time, there will face great consequences, and damages will be occurred. The devastating effects of global warmings, such as Social evils, economic losses, Migration of people across in the world, and extremely hot weather which cause of melting glaciers resulting increasing sea level hence tsunami and flooding in addition deadly hurricanes, wildfires, earthquake and different diseases will occur, (Report School of Earth, Energy \& Environmental Science [17]. Examples of consequences of environmental degradation such as the tsunami in Japan, Indonesia, earth quick in Hattie and Pakistan, wildfire in the USA, Australia and Amazon.

Considering the adverse consequences of the carbon dioxide emission, different researchers used carbon dioxide emission with different independent variables and applied different techniques with different time period, approaches and sample of countries. While this study investigates the impact of trade openness, economic growth, energy consumption and urban population on carbon oxide emission on selected 50 Belt and Road countries using time period 1992 to 2014. The present study extended sample size and variables and applied different technique with previous paper and grouped 50 countries into three regions which fulfill the weak point previous work, Sub H et al., [18] investigated the impact trade openness on $\mathrm{CO} 2$ emission with 49 BRI countries and included trade openness economic growth, energy consumption and CO2 emission, by implies FOLS and DOLS techniques. The finding of this paper will provide guide line for policy maker to understand the relationship and role of included variables in whole sample and different regions group.

The rest of the paper will organize as follows. The next part provides Review of literature. section 3 contain Data and Methodology. Part 4 explain result and discussion. Section 5 present the conclusion and recommendation.

\section{LITERATURE REVIEW}

It is mentioned earlier by number of studies that increase world production seems to coincide with increases environmental degradation. Environmental pollution is a global problem which causes with a wide range of issues comprising global warming, pollution, 
harmful gasses in the atmosphere and becomes cause of catastrophic consequences, different definitions and proxies are signified by the various researchers and Agencies. A numerous study has been done on environment and macroeconomic variables by applied different techniques and for different regions, Trade environment nexus is a burning and hotly debated topic for the last few decades. Many theoretical and empirical studies have scrutinized the impact of foreign trade on environment. Keep regarding international trade where developing countries less concerned about environmental degradation, while developed countries give more priority to environmental quality. Heckscher -Ohlin [19] based factor endowment theory advocate that capital intensive products which generally occurs in industrialized countries that generate dirty goods and reallocate capital abundant factor. Developed counties through FDI can reallocate capital intensive inputs to developing countries and divert pollution [20-22].

Benard \& S.K. Mandal [23] the article probed the effect of trade openness on environmental quality for 60 emerging economies for the period 2002-2012, engaging two indicators $\mathrm{CO}_{2}$ emission and Environmental performance Index, For empirical result GMM and fixed effect approach has been used, for empirical specification employed trade -environment framework with independent and additional variables, e.g, GDP, Energy consumption, FDI, Urbanization, financial development, Political globalization. The fixed-effect model result found out that trade openness and economic growth has a positive impact on environmental performance index, it is also confirmed by Chakraborty and Mukherjee [24] that trade openness and economic growth direct impact on environmental performance index. Nonetheless, trade openness and economic growth, energy consumption, population, FDI, Financial development, urbanization, and income have a positive effect on $\mathrm{CO}_{2}$ emission and as a result, make escalate environmental quality while political factors improve air quality. GMM estimation revealed that most of the variables' significant impact on $\mathrm{CO}_{2}$ emission except trade openness has an insignificant effect on environmental performance index while further found that economic growth deleterious effect on environmental quality. As economic growth rise, environmental performance index will fall. Sharma [25] used a dynamic panel data model for the context of 69 countries and has been reported that trade openness has no significant impact on the environment in the global panel, albeit analyzed that GDP increase $\mathrm{CO}_{2}$ emission and urbanization negatively contributed environmental degradation. Frankel and Rose [26] found a positive effect of trade openness on certain pollutants elements like SO2 emission. All in all, the authors claimed that when endogeneity controlled as a result of political globalization and Governance will accelerate environmental performance index, it is because of the effectiveness of governance initiative, regulation, and legislation for green growth at a global level and national level.

Rauf et al., [27] the authors enlighten the relationship between trade openness economic growth energy combustion, urbanization, financial development for titled Energy and ecological sustainability challenges and panoramas along with Belt and Road for the period 1980-2016, and has been taken 47 countries for analysis's and used different techniques for empirical investigation, e.g. Four unite root test were used such as (LLC, ADF, IPS, and PP) to gauge stationarity of the included variables, to find long-run cointegration among the subjected variables were measured by applying FMOLS and DOLS tests, moreover for robustness used random effect, fixed effect, and pooled regression, and causality was estimated by pair Granger causality test. They found that all variables are bidirectional causality relationship with $\mathrm{CO}_{2}$ emission while trade openness have unidirectional towards environmental quality. Further investigated that panel causative heterogeneous test that all variables associated with carbon dioxide emission positively and significantly while trade openness has negative effected $\mathrm{CO}_{2}$ emission along BRI Economies, the negative correlation of trade openness with $\mathrm{CO}_{2}$ emission, this leads good direction for policymaker regarding trade and environment, additional enlighten that economic growth have positively affected environmental degradation in the long run of all BRI economies because mostly countries are developing and emerging economies who try to accelerate their economic growth based on highly usage gas, coal and oil and without consideration global warming, a notable point that some countries energy consumption mixed effect on $\mathrm{CO}_{2}$ emission because of few developed countries of BRI and the reason behind negative impact of trade on environmental degradation due to individual country-specific policy decision.

Tariku, L [28] analyzed the effect of trade liberalization on environmental degradation in Ethiopia for the time span 1970 to 2010 and utilized Johanson Co-integration and error correction model. He denoted per capita GDP for scale effect, square GDP for technique effect and capital-labor ratio for composition effects, however, he analyzed the long-run relationship among the trade liberalization and environmental degradation. Moreover, the study explained that the scale effect a positive impact on air pollution while composition effect, technique effects, and trade density negative impact on air pollution. More population density and economic growth is positively correlated with environmental degradation in the long run. The negative impact of population density is caused by different human activities directly or indirectly adverse effects on environments and release greenhouse gas into the atmosphere resulting deteriorate environment [29]. In Ethiopia, increasing population density increase carbon dioxide emission and adversely contributed air 
quality. Moreover, the negative impact of composition effect implies the comparative advantage of laborintensive products in Ethiopia and utilization of environmental friendly technologies and clean production while the positive coefficient of scale effect support [30, 31]. Further depicts increase economic activities and generation of output in Ethiopia hence lead worsen air quality. Technique effect (square of GDP) and trade openness reduce environment degradation due to usage of energy efficiency, latest technology, and managerial skill in the production process.

Ertugrul M et al., [32], exploited that the relationship between trade openness, energy consumption, income, and $\mathrm{CO}_{2}$ emission for top 10 developing countries over the period 1971-2011 in the presence of EKC hypothesis and applied zivotAndrews unit root test with a structural break for stationarities, ARDL approach for long run cointegration and VECM were used for granger causality among the variables. They examined that trade openness has an ambiguous impact on $\mathrm{CO}_{2}$ emission, in some emerging economies, it has a significant effect while in some specific nature countries have an insignificant effect on $\mathrm{CO}_{2}$ emission. In addition, indicated the energy consumption, trade openness, $\mathrm{CO}_{2}$ emission, income, and quadratic income cointegrated for Thailand, Turkey, Brazil, China, India, Indonesia, and Korea. They probed that trade openness positively affected $\mathrm{CO}_{2}$ emission in turkey India, China, and Indonesia, the causality also depicted unidirectional causality from trade openness to $\mathrm{CO}_{2}$ emission in the abovementioned countries; hence the validity of the EKC hypothesis is supported in the above countries in the long run. According to Wang et al., [33] enlightened that due to the low level of efficient energy is the main cause of $\mathrm{CO}_{2}$ emission. Almost all emerging countries are using fossil energy, which is an important factor for the production process, and very difficult for developing economies to reduce energy consumption hence increase $\mathrm{CO}_{2}$ emission.

Gulistan A et al., [34] scrutinized the effect trade openness, economic growth, energy consumption and tourism on environmental degradation empirical evidence from global by using Fixed Effect, Random effect GLS and pooled OLS models implied for empirical investigation for the period 1996-2017 and have taken 112 countries for analysis. This study also find out the validation of EKC hypothesis and divide the countries on income base and region base. The findings reveal that trade openness affect positive lower-income, lower-middle and uppermiddle-income countries positive environmental degradation while high-income level countries contributed negatively, on the other hand, the trade openness association inverse with environmental degradation in East Asia Pacific while European and Central Asia, Middle East, and Latina Africa, Latina America and Caribbean, Sub Sahira and Africa, and Middle East and North Africa regions were positively correlated with trade openness. However, energy consumption, economic growth, and tourism were harmful to environmental quality for almost all regions and income levels owing to coal-based energy usage. The validation of environmental Kuznetscurvee is mixed e.g in Latin America and Caribbean region didn't support EKC hypothesis. Besides that, similar results also investigated by Leon et al., [35] and Dogan et al., [36] that tourism upsurge emission in lowermiddle-income economies. While contradictory to this result, trade openness proves that it is good for environment quality by mitigating carbon emission, this result is in line with Dogan and Aslam [36].

Liobikiene and Butkus [37], By implied GMM technique, to analyze the impact of GDP, renewable energy consumption, Foreign direct investment, trade openness, industrialization, urbanization and energy efficiency on greenhouse gas emission considering the channels scale, composition and technique effects, and using global panel data of 147 economies for investigation. However, countries are categorized, such as high income, middle income, lower-income level, and global panel over the period of 1990 to 2012. The general result provides that GDP has a positive and significant impact on Greenhouse gas emission through scale effect or direct effect, whereas energy efficiency trade openness and renewable energy consumption negatively contributed GHG emission while taking into account the indirect impact through technique effect provide an evidence that urbanization, GDP and trade mitigate carbon emission. Moreover, the composition effect no evidence was observed in the included variables. Similarly, FDI, urbanization, and trade openness effect on GHG emission was not observed in scale effect. Additionally, trade has a contradictive effect on GHG through scale effects. Comprehensively trade has no interaction with GHG emission and PPH Hypothesis was not supported while in via technique effect in terms of energy efficiency trade contributed to mitigate GHG emission and confirm the Pollution Halo Hypothesis.

The positive and significant relation with GHG emission is due to the classical theory economic growth, the same result asserted by Chen et al., [38] and Saidi and Hamami [39] that GDP positive and significant contributed to GHG emission in global panel through scale effect, due to different nature economies its results are contradicted, The techniques channel revealed that if GDP used for increasing energy efficiency thereby economic growth reduce environmental degradation, via technique affect the old 
and dirty technologies are being replaced by new and environmental friendly technologies, innovation and managerial skill implication, meanwhile considering the effect of economic growth on GHG emission via composition effect, the coefficient relation of GDP on industries was found statistical insignificant hence no effect observed on GHG emission.

Hao and Yanyang [40], explored the relationship between $\mathrm{CO}_{2}$ emission economic growth, energy consumption and industrial structures along with BRI countries, for the time span 1970-2013. For the empirical estimation used, DOLS, FMOLS and VECM techniques for panel cointegration and causality respectively and has taken total 68 countries of BRI further divided in two groups e.g., exporting countries and importing countries and total energy has been estimated by renewable energy and fossil fuel energy consumption. The findings reported that all variables are cointegrated in the long run and found unidirectional causality running from GDP to renewable energy in the short run and feedback causality in the long run in the energy importing countries likewise relation also investigated in the exporting countries such as unidirectional running from GDP per capita to renewable energy, moreover bidirectional in the long run, with both group of countries perspective the relationship between renewable energy and economic growth found positive but insignificant, Even though the granger causality result for all countries suggested that unidirectional causality running from GDP to carbon dioxide emission, energy consumption and industrial value-added in the short run while reverse causality in the long run. In terms of the long-run dynamics, found feedback causalities among the calculated variables e,g energy use carbon dioxide emission, GDP per capita and industry value added with the absence of renewable energy. It implies that traditional fossil fuel energy is more effective than renewable energy consumption for the fast-growing. Indeed, it is worth noting that the usage of oil an essential source for generating economic growth, additionally, renewable energy is generally government-oriented instead of market-oriented tendency (behavior), that is why its implication and long-run causality does not exist.

However, a member of studies has investigated a positive result between energy consumption and economic growth, Zhang [41], Ahmad et al., [42], different empirical studies analyzed that energy and growth relationship depends on the basis variables selection, econometrics techniques, nature of the people and countries characteristics, especially when traditional method of production are employed, mostly happen in low developing countries [43]. Opposing on, a case of industrial intensive product and developed economies the growth and energy consumption practicing feedback causality and positively correlated, Narayan and Smyth [44], Lee et al., [45].
Chen et al., [2] show the impact of economic growth, square GDP, renewable, nonrenewable energy production and foreign trade on $\mathrm{CO}_{2}$ emission and on the presence of EKC Hypothesis in China for covering the period 1980-2014 and used ARDL bound test and VECM Granger causality approach for empirical findings. They examine the long-run relationship among the included variables and find the positive impact of GDP and non-renewable energy on $\mathrm{CO}_{2}$ emission while renewable energy and foreign trade have adverse effects on $\mathrm{CO}_{2}$ emission. The EKC hypothesis is not valid in China under the influence non- renewable energy, economic growth, and foreign trade, while when renewable energy variable included hence Environmental Kuznets Curve is supported in the long rung in China which leads to reduce $\mathrm{CO}_{2}$ emission and U- shaped EKC hypothesis is valid.

Meanwhile in the short run non-renewable energy and GDP has positive effect on $\mathrm{CO}_{2}$ emission, although square GDP, renewable energy and foreign trade has a negative impact on $\mathrm{CO}_{2}$ emission, The VECM based technique also confirm the exist a longrun Granger causality between the variables, findings explain that long-run Granger causality running from renewable energy use, non- renewable energy consumption, GDP and square GDP and foreign trade to carbon dioxide emission, additionally they also probed long-run Granger causality running from $\mathrm{CO}_{2}$ emission, renewable energy, GDP, square GDP to nonrenewable energy consumption. Further exerted shortrun bidirectional causality between foreign trade and renewable energy consumption and feedback causality between foreign trade and GDP or square GDP while unidirectional causality from $\mathrm{CO}_{2}$ emission to renewable energy use. There exists a one-way causality from GDP and foreign trade to $\mathrm{CO}_{2}$ emission, in addition in the short run foreign trade unidirectional cause non- renewable energy. There are some basic causes mentioned by authors, China economy mainly depend non- renewable energy e.g. heavy depend on coal consumption, its total share of energy consumption of coal $76.5 \%$ followed by oil $8.9 \%$ and natural gas $4.3 \%$ while the share renewable energy $9.4 \%$, the effective role of trade in reducing $\mathrm{CO}_{2}$ emission because the demand of renewable energy increasing in international makers, obviously China significantly contribute in producing and exporting in photovoltaic cell production at around $56.5 \%$ of the total global production by the end of 2014. According to (IEA) that China is the world's largest solar photovoltaic panel and wind power producer and exports it. Moreover, China import capital goods like machines and related equipment from developed countries, which are used in producing renewable energy; hence trade openness promotes renewable energy consumption and negatively affected $\mathrm{CO}_{2}$ emission in China. 


\section{DATA AND METHODOLOGY}

The current study used annual data for the period from 1992 to 2014 for the selected 50 Belt and Road initiative countries, the data complied carbon oxide emission, trade openness, output, energy consumption and urban population. Further grouped these countries into three regions, namely Asian regions, Middle East and North Africa, European countries. The selection of 50 countries are on the basis for higher emission and data availability in BRI countries.

Various indicators are used to measure environmental pollution in the literature, such as $\mathrm{SO}$, $\mathrm{NO}$, and $\mathrm{CO}_{2}$ emission, but the ratio of $\mathrm{CO}_{2}$ emission is much higher than the rest of pollutants. First, the ratio of $\mathrm{CO}_{2}$ emission of more than $60 \%$ in GHG. Secondly, Carbon dioxide emission ambient half-life is higher than other relevant air pollutant indicators [46].

Moreover, the length of the three air pollutants gases ambient half-life as explain that the NO ambient half-life is from 3 to 5 hours, and $\mathrm{SO}_{2}$ ambient half-life is from 6 to one day, while $\mathrm{CO}_{2}$ emission has the longest ambient half-life which approximately 27 years respectively [47-49]. Nevertheless, the study employ $\mathrm{CO} 2$ emission for analysis due to comparative higher ratio in greenhouse gas emission, its global effect and health problems linked with $\mathrm{co} 2$ emission. Statistical package Stata 15 were used for estimation. the study defines Carbon dioxide emission with relation trade openness, energy consumption, economic growth and urban population.

The estimation model as given below

$$
\mathrm{CO} 2_{\mathrm{it}}=f\left(\mathrm{TO}_{\mathrm{it},}, \mathrm{GDP}_{\mathrm{it}}, \mathrm{EC}_{\mathrm{it}}, \mathrm{UP}_{\mathrm{it})}\right.
$$

The study alters the model into natural logarithm to minimize heteroscedasticity problem and taking its natural of dependent and independent variables

$$
\operatorname{lnCO} 2 \mathrm{it}=\beta 0+\beta_{1} \ln \mathrm{T}_{\mathrm{it}}+\beta_{2} \operatorname{lnGDPit}+\beta_{3} \operatorname{lnEC} \mathrm{C}_{\mathrm{it}}+
$$
$\beta_{4} \operatorname{lnUP}_{\text {it }}+$ eit

Where $\beta 0$ shows intercept, while $\mathrm{i}$ and $\mathrm{t}$ are represented countries and time respectively, and $\beta \mathrm{i}$ indicates the slope of their respective variables. $\ln \mathrm{CO}_{2 \mathrm{it}}$ denotes the natural $\log$ of carbon dioxide emission, $\operatorname{lnTR} R_{t}$ indicates the natural $\log$ of trade openness, lnGDPit shows natural $\log$ of economic growth, $\operatorname{lnEC_{it}}$ indicates natural log energy consumption, $\operatorname{lnUP}_{\text {it }}$ shows natural $\log$ of urban population and The error term is represented cit of the model.

The paper investigate model by pooled ordinary least square, Huaman test specification and Feasible generalized least square, by Hausman specification test is a basic determinant and using to check which model is the most appropriate, either fixed-effect or Random effect for correct empirical results and for accurate data analysis. Generally, Hausman [50] test performed to see a correlation between the regressors and the unique errors or with individual effect in the model and detect endogeneity in the regression. According to the ordinary least square (OLS), there will be no correlation between predictors or regressors and error terms. Hence Hausman test applies to identify whether Random effect model will be preferred or Fixed effect will be preferred for the estimation. Even in this condition researcher deploy a Hausman test for ultimate methodology decision, which model needs to use, assuming that explanatory variables and individual unobservable effect or heterogeneity are correlated hence recommend fixed effect, if not correlated regressors with individual error component or individual differences then Random effect model can be applied for estimation [51]. According to Fielding [52] that it is merely a diagnostic procedure of one particular estimation, which associated with fixed effect and random effect model. Generalized least square (GLS) is applies to check the robustness of fixed effect approach. Moreover, GLS model is robust and control data is being heteroscedasticity and auto correlated.

\section{RESULTS AND DISCUSSION}

The study engaged potential economic indicators -environment nexus on the bases of literature and also focused on those variables which have been used in past studies. Carbon dioxide emission is the dependent variable and measures proxy for environmental pollution, which mainly generated from the combustion of fossil fuels (coal, oil, and gas) and the other relevant emission sources. There are several proxies for global warming and environmental pollution, but the most suitable and mostly used is $\mathrm{CO}_{2}$ emission because its parentage ratio in greenhouse gas is more than $60 \%$ [53], this proxy has been used by [27]. Trade openness is the main independent variable which defines sum up export and import \% of GDP. It is the most potential variable for the environment and previously used by [23]. GDP considers an effective variable and most responsible for the deleterious effect on air quality because of scale effect, it has several proxies, but the study defines its proxy per capita in constant 2010 US dollar, which eradicates the inflation effect and used by [40]. Further, Energy consumption determines kilo of oil equivalent per capita e.g. Fossil fuel, energy consumption accelerates carbon dioxide and the main cause of emission as well as improves the living standard of humans, previously employed Giray Gozgori 2017 [23]. Additionally, the proportion of energy-intensive $\mathrm{CO}_{2}$ emission is about $80 \%$ in Belt and Road, which shows the crucial contribution of energy consumption in emission because China mostly depends on coal base energy [27]. According to university of applied Science Potsdam report (2010 and 2013) stated that $76 \%$ of all green gas comes from energy production that's the energy combustion fossil 
fuel especially coal base globally. Foreign direct investment indicates the net inflow of percentage of GDP used by [54]. Urbanization shows the \% of urban population of the country, and almost it escalates environmental degradation while promoting economic growth, on the contrary it can reduce $\mathrm{CO}_{2}$ emission vie infrastructure improvements, Sadorsky A [55]. The study employed relevant variables for investigating carbon dioxide emission, and data has been collected from different sources. Carbon dioxide, Trade Openness GDP, Energy consumption (EC), urbanization population as illustrated in Table-1.

Table-1: Variables description and data sources

\begin{tabular}{|l|c|l|c|}
\hline \multicolumn{1}{|c|}{ Variable } & Acronym & Measure Source & Time span \\
\hline Carbon dioxide emission & $\mathrm{CO}_{2}$ & Metric tons per capita & WDI 1992-2014 \\
\hline Trade openness & TO & The sum of import and export as \% of GDP & WDI 1992-2014 \\
\hline Economic growth & GDP & GDP per capita in constant 2010 USD & WDI 1992-2014 \\
\hline EC Energy consumption & EC & Kg of oil equivalent per capita & WDI 1992-2014 \\
\hline Urban Population & UP & Percentage of urban population in the country & WDI 1992-2014 \\
\hline
\end{tabular}
Source: Author tabulated

\section{Descriptive Statistics}

Summary information in dataset obsoletely crucial before begin the process for conducting empirical estimation, descriptive statistics describe the characteristics of the variables and summarize each individual variable information and will give a good idea on the data which working with it. It encompasses mean minimum, maximum, and standard deviation and number of observation. These elaborate the average and range of the dataset while standard deviation signifies that how far observation are from its mean value, or it measures the dispersions and spreading of score around the mean. It covers 50 entities of BRI and time period 23 years of panel dataset.

Table-2 present descriptive statistics and a cursory look at the data nature. The total observation of carbon dioxide emission is 1149 ; its mean value is
1.210914, while standard deviation 1.490757, the lowest value -2.706622 and highest value 5.132804. The total observation 1,142 of trade openness, the mean value 4.223974 , the standard deviation which specify from the mean .8901059 , the minimum value -1.787264 while the maximum value6.08068. The mean of Gross domestic product is 8.276986, while the standard deviation 1.280262, the highest value of GDP is 3.729789, whereas the lowest value of GDP is11.08006. Similarly, the mean value of energy consumption is 7.22591, and its dispersion value from mean is 1.030971, the range value of energy consumption from highest to lowest 9.425996, 4.809962 respectively. The mean of urban population is 4.334263, while its standard deviation 2.068178, and the highest value is 14.7303 and the lowest value is 2.259886

Table-2: Descriptive statistics

\begin{tabular}{|c|c|c|c|c|c|}
\hline Variables & Obs & Mean & Std.Dev & Min & Max \\
\hline LnCo2 & 1,149 & 1.210914 & 1.490757 & -2.706622 & 5.132804 \\
\hline LnTO & 1,142 & 4.223974 & .8901059 & -1.787264 & 6.08068 \\
\hline LnGDP & 1,149 & 8.276986 & 1.280262 & 3.729789 & 11.08006 \\
\hline LnEC & 1,150 & 7.22591 & 1.030971 & 4.809962 & 9.425996 \\
\hline LnUP & 1,150 & 4.334263 & 2.068178 & 2.259886 & 14.7303 \\
\hline
\end{tabular}

Source: Author' computations

Table-3 reports the correlation matrix, that explain about correlation and respective probability results among variables, according to result card relevant variables are correlated at different nature of strength $\mathrm{CO}_{2}$ emissions is negatively connected with trade openness while energy consumption, economic growth, and population are positively correlated, whereas economic growth (GDP), energy consumption and population are positively linked with TR. Almost all variables are direct association with each other. The overall result unbiased and well fitted correlation, owing to all variables is statistically significant interrelated.

Table-3: Correlation Matrix

\begin{tabular}{|l|l|l|l|l|l|}
\hline & $\mathbf{1}$ & $\mathbf{2}$ & $\mathbf{3}$ & $\mathbf{4}$ & $\mathbf{5}$ \\
\hline $\mathrm{LnCO}_{2}$ & 1.0000 & & & & \\
\hline LnTO & $-0.0775^{*}$ & 1.0000 & & & \\
\hline LnGDP & $0.8085^{*}$ & $0.1645^{*}$ & 1.0000 & & \\
\hline LnEC & $0.8158^{*}$ & $0.1923^{*}$ & $0.7411^{*}$ & 1.0000 & \\
\hline LnUP & $0.6820^{*}$ & $-0.5346^{*}$ & $0.3195^{*}$ & $0.3454^{*}$ & 1.0000 \\
\hline
\end{tabular}

Source: Author' computations 
Table-4 presents the variance inflation factor which apply to check the multi collinearity in the data set. According to the rule of thumb that when the value of variance inflation factor is not more than 10 , or the value $1 / \mathrm{VIF}$ tolerate insignificance and more than 0.05

Table-4: VIF

\begin{tabular}{|l|l|l|}
\hline Variable & VIF & 1/VIF \\
\hline LnGDP & 4.61 & 0.216826 \\
\hline LnEC & 4.10 & 0.243607 \\
\hline LnUP & 1.69 & 0.591378 \\
\hline LnTO & 1.61 & 0.621815 \\
\hline Mean VIF & 3.00 & \\
\hline
\end{tabular}

The table result indicate that no multicolinearity because all the value is less than 10 and the value of $1 / \mathrm{VIF}$ is greater than .05 .

Table-5: Relationship among, trade openness, energy consumption, GDP, Urban Papulation and CO2 emission in the whole sample

\begin{tabular}{|l|l|l|}
\hline Variable & Fixed effect & GLS \\
\hline LnTO & $\begin{array}{l}-.0207474 * \\
(-1.86)\end{array}$ & $\begin{array}{l}-.0328939 * * * \\
(-2.22)\end{array}$ \\
\hline LnGDP & $\begin{array}{l}.0759066 * * * \\
(6.53)\end{array}$ & $\begin{array}{l}.0839347 * * * \\
(5.04)\end{array}$ \\
\hline LnEC & $\begin{array}{l}1.060539 * * * \\
(36.21)\end{array}$ & $\begin{array}{l}1.003659 * * * \\
(46.09)\end{array}$ \\
\hline LnUP & $\begin{array}{l}.4112857 * * * \\
(5.79)\end{array}$ & $\begin{array}{l}.2870207 * * * \\
(43.64)\end{array}$ \\
\hline Cons & $-8.76636 * * *$ & $-8.109514 * * *$ \\
& $(-35.79)$ & $(-97.36)$ \\
\hline Number of obs $=1,141$ & \\
\hline Number of groups $=50$ & \\
\hline Obs per group: & \\
\hline min $=15$ & avg $=22.8$ \\
\hline max $=23$ & F(4,1087) $=756.84$ \\
\hline Prob $>$ F $=0.0000$ & \\
\hline Wald chi2(4) $=18947.29$ \\
\hline Prob > chi2 $=0.0000$
\end{tabular}

Table-5 reported the whole sample 50 Belt and Road countries findings and applied two techniques Fixed effect and GLS estimator, according to the result the coefficient of trade openness is found negative and statistically significant with $\mathrm{CO}_{2}$ emission in all the both models.

It shows that one unite increase trade openness leads to mitigate carbon dioxide. -0-.0207474 and .0328939 in Fixed effect, and GLS model respectively. here the study main focus on Fixed effect while as GLS estimator is robustness, These findings are consistent with findings of they also found the same correlation between these two variables [34, 27, 8]. Moreover, the result also similar findings with [56-59], they suggest that trade openness enhances the technology transformation, shifting pollution-intensive goods from developing entities to advance countries and government environmental policies hence reduce $\mathrm{CO}_{2}$ emission. Gozgor $\mathrm{G}$ [60] documented that the negative association with trade, as trade bring innovation and technological progress and termed that trade openness as the proxy of technological progress as a result mitigate carbon dioxide emission. The study suggests that traded modern technologies, energy-efficient sources, renewable technology, and shifting pollutionintensive goods among the BRI countries it leads that trade openness renders environmental degradation.

The per capita GDP has a positive impact on carbon dioxide emission in both model that indicate that one unite change per capita GDP leads to .0759066 , .0839347 in fixed effect, and Gls estimation respectively. The positive impact of income exhibits scale effect of the economy that as income rise it leads to increase $\mathrm{CO}_{2}$ emission, the result is in line with findings Rauf A et al., [27], Omri et al., [61], Antweiler et al., [7] and Arouri et al., [62]. The trade flow makes large market size and allow industries and firms to expand economies activities i.e. production of good and services, thereby worsen environmental qualities and entail more pollution. Energy consumption is shown that statistically significant and positive associated with $\mathrm{CO}_{2}$ emission in all mode, their coefficient shows that 
one unite change increase $\mathrm{CO}_{2}$ emission 1.060539 and 1.003659 in respected model, this confirms the similar result $[34,63,64,33,62,23,65]$ energy consumption is the essential factor of production and occur due to economic growth which generates $\mathrm{CO}_{2}$ emission hence release into the environment. Urbanization has a positive and significant contribution to carbon dioxide emission, which indicates that urban population increase $\mathrm{CO}_{2}$ emission by .4112857 and .2870207 percent in model 2 and model 3 respectively, the same finding consistent with previous study [27].

Table-6: Relationship between GDP, energy consumption, trade, urban population, and $\mathrm{CO}_{2}$ emissions in three main regions of the $B R I$

\begin{tabular}{|l|l|l|l|l|l|l|}
\hline \multirow{2}{*}{ Variable } & \multicolumn{2}{|l|}{ Middle East and North Africa } & Asian countries & \multicolumn{2}{l|}{ European Region } \\
\cline { 2 - 7 } & Pool & RE & FE & GLS & FE & GLS \\
\hline LnTO & $-.06071^{* *}$ & -.00837 & $-.0138^{*}$ & $-.02341^{*}$ & $-.11687^{* * *}$ & $-.4316^{* * *}$ \\
& $(-2.51)$ & $(-0.22)$ & $(-01.88)$ & $(-01.74)$ & $(-3.9)$ & $(-14.4)$ \\
\hline LnGDP & $.09359 * * *$ & $.08312 * * *$ & $.2156^{* * *}$ & $.1343^{* * *}$ & $.05355^{* * *}$ & $.00956^{*}$ \\
& $(4.8)$ & $(2.00)$ & $(5.1)$ & $(3.1)$ & $(4.7)$ & $(1.84)$ \\
\hline LnEC & $.8107 * * *$ & $.8245^{* * *}$ & $.9609 * * *$ & $1.0725 * * *$ & $1.1828^{* * *}$ & $1.1788^{* * *}$ \\
& $(40.4)$ & $(20.1)$ & $(13.8)$ & $(18.4)$ & $(30.4)$ & $(41.3)$ \\
\hline LnUP & $.2237 * * *$ & $.15384 *$ & $.3913^{* * *}$ & $.9925^{* * *}$ & $.26470^{*}$ & $.15141^{* * *}$ \\
& $(6.08)$ & $(1.69)$ & $(3.15)$ & $(13.02)$ & $(1.81)$ & $(18.12)$ \\
\hline Cons & $-5.925^{* * *}$ & $-5.941^{* * *}$ & $-9.033 * * *$ & $-9.451^{* * *}$ & $-8.521^{* * *}$ & $-6.1816 * * *$ \\
& $(-56.76)$ & $(-21.8)$ & $(-32.2)$ & $(-60.7)$ & $(-11.3)$ & $(-29.5)$ \\
\hline F-statistics & 4968.91 & ------- & 302.80 & ------ & 353.64 & ------ \\
\hline Prob > F $=$ & 0.0000 & & 0.000 & & 0.000 & 0.0000 \\
\hline Housman Test & 6.31 & & 8.53 & & 16.86 & \\
\hline Prob>chi2 $=$ & .1452 & & $(.051)$ & & 0.0021 & \\
\hline
\end{tabular}

Source: Author Tabulation

The Table- 6 reported the results of regions wise of BRI countries and grouped into three regions recording to exactly included in the whole sample. The results of the Middle East and North Africa regions are investigated by pooled OLS and Random effects while the results of Asian countries and European Region results are obtained through fixed effect and GLS model (generalized least square). The result of middle East and North Africa exhibited that trade openness has negative and significant effect on carbon dioxide emission in Pooled OLS and random effect has negative but insignificant contributed $\mathrm{CO} 2$ emission, its coefficient magnitude -.06071 and -.00837, while GDP energy consumption and population has positive and statistical significant effected $\mathrm{CO} 2$ emission, in the literature the same result are reported Gulistan A et al., [34]. The second and third regions selected countries results obtained by applied Fixed effect and GLS and found almost similar results where trade openness mitigate carbon emission but its impact on carbon dioxide emission in Asian selected countries at $10 \%$ level of significant, its coefficient magnitude -.0138 and .02341 , while the European countries $.01 \%$ level of significant in both approach, while remaing variables GDP energy consumption and population has positive and significant contributed $\mathrm{CO} 2$ emission, this finding are aligned with past work, Dgan and Aslan [36] and Gulistan A et al., [34]. Thus trade openness is beneficial for environmental quality because it reduces carbon emission in all groups.

\section{CONCLUSION AND RECOMMENDATION}

The main objective of this study is to determine the impact of trade openness, economic growth, energy consumption and population on carbon dioxide emission in One Belt and One Road using panel data of 50 countries over the period 1992-2014, and the time spanned period 23 years. Countries are restricted 50 due to the availability of data, and the selected countries are almost the key and active partners of BRI. Further grouped this country into three regions Middle East and North Africa, European Region and Asian countries and for checking multicollinearity in the data set, used variance inflation factor (VIF). However, the present study implemented different panel data econometric approaches to measure the impact of included variables on $\mathrm{CO}_{2}$ emission. Which comprise Pooled OLS, Random effect, Fixed effect model, and GLS estimator; through the Hausman specification test verified that Fixed effect model is appropriate for empirical estimation to capture the country-specific unobserved heterogeneity and traditional endogeneity. Furthermore, for the more accurate result was measured by employed GLS estimator.

Comprehensively, BRI is the development strategies proposed by China that focus on stimulating variety of sectors and bringing huge opportunities for development, prosperities, and potential mutual benefits for China and connected countries. It is constructed around two main Routes, the Silk Road Economic Belt (land base Route) and $21^{\text {st }}$ Century Maritime Silk Road (ocean base Route), which further organized in 6 economic corridors in different regions. China is the key stakeholder of this largest megaproject, therefore the foremost aim of BRI to link China with 6 Regions which are geographically located among the BRI. The total number of countries of BRI is 65 , which mostly 
developing and emerging economies. However, the relevant countries' individual characteristic are quite different and heterogeneity among them regarding economically culturally and geographically. Though, they comprise $38.5 \%$ out of the global land area while the population ratio $62.3 \%$ of the world and the GDP ratio of the BRI $30 \%$ of out of global, China itself has a major part of GDP.

The study found the main result for whole sample and region wise through fixed effect, random effect ,Pooled and GLS approach that trade openness negative and significant impact on $\mathrm{CO}_{2}$ emission almost significantly, this shows that trade openness mitigate carbon dioxide emission, GDP has direct and significant impact on $\mathrm{CO}_{2}$ emission which implies that GDP per capita increase $\mathrm{CO}_{2}$ emission in the panel data. The study finds that energy consumption contributed $\mathrm{CO}_{2}$ emission significantly in all models, this signifies that fossil fuel energy dominated in production activities. Moreover, urbanization has a statistically significant and positive impact on $\mathrm{CO}_{2}$ emission in all models. This elicits that urbanization is one of the key variable that accelerated carbon dioxide emissions in all results.

The minor difference in result is due to the differences of techniques, this the first study which employs fixed effect and GLS estimator for this relevant region.

The negative correlation of trade openness with $\mathrm{CO}_{2}$ emission owing to some developed countries in that region and some labors factor endowments nature countries. The developed countries that heavily depend on renewable energy sources, as a result, their carbon dioxide emission are getting mitigating. The leading country China mostly export clean environment technologies to regional connected countries.

This study is the first-ever made endeavored to scrutinize the mentioned variables for BRI region and the authors believe the findings is holistic and robust that will provide accurate guideline and policy implication for BRI countries, Consistent with above findings the study recommends and suggest to the policymaker to focus on trade promotion among the BRI region by trading renewable energy sources, environmental friendly suppliers, and efficacy technology, i.e. wind power, geothermal heat, sunlight, solar power, hydropower, biomass power, waste base energy and employ environmental regulation policies such as impose carbon tax or quota system on emissionintensive products which could help to reduce environmental degradation. Furthermore, the connected countries should divert the pattern of production nature and investment from coal-based energy to renewable energy. The developing countries could expand trade with China and connected relevant countries by importing eco-environmental technologies and green energy base usage, which has a very large potential role in sustainable ecological development and for clean environments. Climate change is a global issue so the developed and industrialized countries should help the developing countries to generate power capacity reorganize energy saving efficiency and renewable energy machinery to reduce emission. Even though, a good climate policy can make a balance between interest, cooperation, and sustainable emissions. It's essential for countries to take ambition action for a clean environment, promote eco-friendly trade and implement Pollution Halo Hypothesis policies.

\section{REFERENCES}

1. Zou, W., Kumaraswamy, M., Chung, J., \& Wong, J. (2014). Identifying the critical success factors for relationship management in PPP projects. International Journal of Project Management, 32(2), 265-274.

2. Chen, M. X., \& Lin, C. (2018). Foreign Investment across the Belt and Road: Patterns, Determinants, and Effects. The World Bank.

3. Boffa, M. (2018). Trade linkages between the Belt and Road economies. World Bank Policy Research Working Paper, (8423).

4. EIA, U. (2013). International energy statistics. Washington DC: US Energy Information Administration.(http://www. eia. gov/cfapps/ipdbproject/IEDIndex3. cfm.

5. World Bank, W. (2015). World development indicators (WDI) 2015.

6. Kumbaroglu, G., Karali, N., \& Arikan, Y. (2008). CO $\{$ sub 2\}, GDP and RET: An aggregate economic equilibrium analysis for Turkey.

7. Antweiler, W., Copeland, B. R., \& Taylor, M. S. (2001). Is free trade good for the environment? American economic review, 91(4), 877-908.

8. Shahbaz, M., \& Leit ̃̃, N. C. (2013). Portuguese carbon dioxide emissions and economic growth: a time series analysis. Bulletin of Energy Economics (BEE), 1(1), 1-7.

9. Tang, C. F., \& Tan, B. W. (2015). The impact of energy consumption, income and foreign direct investment on carbon dioxide emissions in Vietnam. Energy, 79, 447-454.

10. Chen, S. T., Kuo, H. I., \& Chen, C. C. (2007). The relationship between GDP and electricity consumption in 10 Asian countries. Energy Policy, 35(4), 2611-2621.

11. Narayan, P. K., Narayan, S., \& Popp, S. (2010). Does electricity consumption panel Granger cause GDP? A new global evidence. Applied Energy, 87(10), 3294-3298.

12. Al-Mulali, U., \& Ozturk, I. (2015). The effect of energy consumption, urbanization, trade openness, industrial output, and the political stability on the environmental degradation in the MENA (Middle East and North African) region. Energy, 84, 382389. 
13. Eia, U. S. (2014). Annual energy outlook. US Energy Information Administration: Washington, DC, Tech. Rep. DOE/EIA-0383.

14. Rauf, A., Liu, X., Amin, W., Ozturk, I., Rehman, O. U., \& Hafeez, M. (2018). Testing EKC hypothesis with energy and sustainable development challenges: a fresh evidence from belt and road initiative economies. Environmental Science and Pollution Research, 25(32), 3206632080.

15. Stern, N., \& Taylor, C. (2007). Climate change: Risk, ethics, and the Stern review. Science, 317(5835), 203-204.

16. Veldman, J. W., Overbeck, G. E., Negreiros, D., Mahy, G., Le Stradic, S., Fernandes, G. W., ... \& Bond, W. J. (2015). Tyranny of trees in grassy biomes. Science, 347(6221), 484-485.

17. Kovalev, I. V., Voroshilova, A. A., \& Borisova, E. A. (2019, August). Overview of the International Conference on Agribusiness, Environmental Engineering and Biotechnologies-AGRITECH2019. In IOP Conference Series: Earth and Environmental Science (Vol. 315, No. 1, p. 011001). IOP Publishing.

18. Cheong, C. H., Kang, H., Kim, D. H., Kim, Y. S., Kim, H. S., Bo-Yeon, N. A., ... \& Kwang-Sub, S. O. N. (2020). U.S. Patent No. 10,534,900. Washington, DC: U.S. Patent and Trademark Office.

19. Heckscher, E. F., \& Ohlin, B. G. (1991). Heckscher-Ohlin trade theory. The MIT Press.

20. Jaffe, A. B., Peterson, S. R., Portney, P. R., \& Stavins, R. N. (1995). Environmental regulation and the competitiveness of US manufacturing: what does the evidence tell us?. Journal of Economic literature, 33(1), 132-163.

21. Cole, M. A., \& Elliott, R. J. (2003). Determining the trade-environment composition effect: the role of capital, labor and environmental regulations. Journal of Environmental Economics and Management, 46(3), 363-383.

22. Cole, M. A., \& Elliott, R. J. (2005). FDI and the capital intensity of "dirty" sectors: a missing piece of the pollution haven puzzle. Review of Development Economics, 9(4), 530-548.

23. Bernard, J., \& Mandal, S. K. (2016). The impact of trade openness on environmental quality: an empirical analysis of emerging and developing economies. WIT Trans Ecol Environ, 203, 195208.

24. Chakraborty, D., \& Mukherjee, S. (2013). How do trade and investment flows affect environmental sustainability? Evidence from panel data. Environmental Development, 6, 34-47.

25. Sharma, S. S. (2011). Determinants of carbon dioxide emissions: empirical evidence from 69 countries. Applied Energy, 88(1), 376-382.

26. Frankel, J. A., \& Rose, A. K. (2005). Is trade good or bad for the environment? Sorting out the causality. Review of economics and statistics, 87(1), 85-91.

27. Rauf, A., Liu, X., Amin, W., Ozturk, I., Rehman, O., \& Sarwar, S. (2018). Energy and ecological sustainability: Challenges and panoramas in belt and road initiative countries. Sustainability, 10(8), 2743.

28. Tariku, L. (2015). The Impact of Trade Liberalization on Air Pollution: In Case of Ethiopia. International Journal of Energy Economics and Policy, 4(3), 465-475.

29. Hitam, S., Suhaimi, S. N., Noor, A. S., Anas, S. B., \& Sahbudin, R. K. (2012). Performance analysis on 16-channels wavelength division multiplexing in free space optical transmission under tropical regions environment. Journal of Computer Science, 8(1), 145.

30. Grossman, G. M., \& Krueger, A. B. (1991). Environmental impacts of a North American free trade agreement (No. w3914). National Bureau of Economic Research.

31. Grossman, G. M., \& Krueger, A. B. (1995). Economic growth and the environment. The quarterly journal of economics, 110(2), 353-377.

32. Ertugrul, H. M., Cetin, M., Seker, F., \& Dogan, E. (2016). The impact of trade openness on global carbon dioxide emissions: Evidence from the top ten emitters among developing countries. Ecological Indicators, 67, 543-555.

33. Wang, Q., Chiu, Y. H., \& Chiu, C. R. (2015). Driving factors behind carbon dioxide emissions in China: A modified production-theoretical decomposition analysis. Energy Economics, 51, 252-260.

34. Gulistan, A., Tariq, Y. B., \& Bashir, M. F. (2020). Dynamic relationship among economic growth, energy, trade openness, tourism, and environmental degradation: fresh global evidence. Environmental Science and Pollution Research, 1-11.

35. León, C., Berndsen, R., \& Renneboog, L. (2014). Financial stability and interacting networks of financial institutions and market infrastructures. European Banking Center Discussion Paper Series, (2014-011).

36. Dogan, E., \& Aslan, A. (2017) Exploring the relationship among $\mathrm{CO} 2$ emissions, real GDP, energy consumption and tourism in the EU and candidate countries: evidence from panel models robust to heterogeneity and cross-sectional dependence. Renew Sust Energ Rev 77: 239-245. https://doi.org/10.1016/j.rser.2017.03.111

37. Liobikienè, G., \& Butkus, M. (2019). Scale, composition, and technique effects through which the economic growth, foreign direct investment, urbanization, and trade affect greenhouse gas emissions. Renewable energy, 132, 1310-1322.

38. Chen, S. L., Yu, H., Luo, H. M., Wu, Q., Li, C. F., \& Steinmetz, A. (2016). Conservation and sustainable use of medicinal plants: problems, 
progress, and prospects. Chinese medicine, 11(1), 37.

39. Safdar, N., Chaudhry, I. S., \& Chaudhry, M. O. (2019). Energy Consumption, Environmental Degradation and Economic Growth in Developing Countries. Pakistan Journal of Social Sciences (PJSS), 39(2).

40. Liu, Y., \& Hao, Y. (2018). The dynamic links between $\mathrm{CO} 2$ emissions, energy consumption and economic development in the countries along "the Belt and Road". Science of the Total Environment, 645, 674-683.

41. Wei, S. J., \& Zhang, X. (2011). The competitive saving motive: Evidence from rising sex ratios and savings rates in China. Journal of political Economy, 119(3), 511-564.

42. Ahmad, L. M., Ahmad, S. A., \& Smith, Z. (2016). U.S. Patent No. 9,351,684. Washington, DC: U.S. Patent and Trademark Office.

43. Sönmez, İ. (2009). Atık Mantar Kompostu ve Karafil Atıklarinin Kompostlanmasi ve Karanfil Yetiştiriciliğinde Kullanılma Olanakları (Doctoral dissertation, Doktora Tezi, Akdeniz Üniversitesi, Fen Bilimleri Enstitüsü).

44. Narayan, P. K., \& Prasad, A. (2008). Electricity consumption-real GDP causality nexus: Evidence from a bootstrapped causality test for 30 OECD countries. Energy policy, 36(2), 910-918.

45. Lee, Y., Choi, J. R., Lee, K. J., Stott, N. E., \& Kim, D. (2008). Large-scale synthesis of copper nanoparticles by chemically controlled reduction for applications of inkjet-printed electronics. Nanotechnology, 19(41), 415604.

46. Yang, C. M., \& Liu, H. W. (2015). U.S. Patent No. 9,214,987. Washington, DC: U.S. Patent and Trademark Office.

47. Boon, E. M., \& Marletta, M. A. (2006). Sensitive and Selective Detection of Nitric Oxide Using an $\mathrm{H}-\mathrm{NOX}$ Domain. Journal of the American Chemical Society, 128(31), 10022-10023.

48. Brimblecombe, N., Shaw, M., \& Ormston, M. (1996). Teachers' intention to change practice as a result of Ofsted school inspections. Educational Management \& Administration, 24(4), 339-354.

49. Watkins, W. M., \& Mosobo, M. (1993). Treatment of Plasmodium falciparum malaria with pyrimethamine-sulfadoxine: selective pressure for resistance is a function of long elimination halflife. Transactions of the Royal Society of Tropical Medicine and Hygiene, 87(1), 75-78.

50. Hausman, J. A. (1978). Specification tests in econometrics. Econometrica: Journal of the econometric society, 1251-1271.

51. Greene, J., \& Hibbard, J. H. (2012). Why does patient activation matter? An examination of the relationships between patient activation and health-related outcomes. Journal of general internal medicine, 27(5), 520-526.
52. Fielding, M. (2004). 'New wave'student voice and the renewal of civic society. London Review of Education, 2(3), 197-217.

53. Ozturk, I., \& Acaravci, A. (2010). CO2 emissions, energy consumption and economic growth in Turkey. Renewable and Sustainable Energy Reviews, 14(9), 3220-3225.

54. Tiba, S., \& Frikha, M. (2018). Income, trade openness and energy interactions: Evidence from simultaneous equation modeling. Energy, 147, 799-811.

55. Sadorsky, P. (2014). The effect of urbanization on $\mathrm{CO} 2$ emissions in emerging economies. Energy Economics, 41, 147-153.

56. Zhang, H., Xu, T., Li, H., Zhang, S., Wang, X., Huang, X., \& Metaxas, D. N. (2017). Stackgan: Text to photo-realistic image synthesis with stacked generative adversarial networks. In Proceedings of the IEEE international conference on computer vision (pp. 5907-5915).

57. Shabaz, M. V., Quick, R. L., Louw, F. R., Lubock, P., \& Safabash, J. H. (2016). U.S. Patent No. 9,408,592. Washington, DC: U.S. Patent and Trademark Office.

58. Copeland, B. R., \& Taylor, M. S. (2004). Trade, growth, and the environment. Journal of Economic literature, 42(1), 7-71.

59. McCarney, G. R., Armstrong, G. W., \& Adamowicz, W. L. (2006). Implications of a market for carbon on timber and non-timber values in an uncertain world (No. 523-201637724).

60. Gozgor, G., \& Ongan, S. (2017). Economic policy uncertainty and tourism demand: Empirical evidence from the USA. International Journal of Tourism Research, 19(1), 99-106.

61. Omri, A., Daly, S., Rault, C., \& Chaibi, A. (2015). Financial development, environmental quality, trade and economic growth: What causes what in MENA countries. Energy Economics, 48, 242-252.

62. Arouri, M. E. H., Youssef, A. B., M'henni, H., \& Rault, C. (2012). Energy consumption, economic growth and $\mathrm{CO} 2$ emissions in Middle East and North African countries. Energy policy, 45, 342349.

63. Ziaei, S. M. (2015). Effects of financial development indicators on energy consumption and $\mathrm{CO} 2$ emission of European, East Asian and Oceania countries. Renewable and Sustainable Energy Reviews, 42, 752-759.

64. Shi, Y., \& Massagué, J. (2003). Mechanisms of TGF- $\beta$ signaling from cell membrane to the nucleus. Cell, 113(6), 685-700.

65. Nogueira, R. G., Jadhav, A. P., Haussen, D. C., Bonafe, A., Budzik, R. F., Bhuva, P., ... \& Sila, C. A. (2018). Thrombectomy 6 to 24 hours after stroke with a mismatch between deficit and infarct. New England Journal of Medicine, 378(1), $11-21$. 